\title{
Think Tanks: New Organizational Actors in a Changing Swedish Civil Society
}

\author{
Pelle Åberg ${ }^{1} \cdot$ Stefan Einarsson $^{2}$ (i) $\cdot$ Marta Reuter $^{3}$
}

Published online: 21 October 2019

(C) The Author(s) 2019

\begin{abstract}
Policy institutes, or "think tanks", are becoming increasingly ubiquitous in our societies. In this article, we conceptualize think tanks explicitly as a civil society phenomenon, linking the proliferation of this relatively new type of actor to the transformation of civil society structures and of systems of interest representation. Using the case of Sweden as an illustration, we argue that the recent decades' rise of think tanks in institutional settings outside of the USA can only be understood if we take into account the particular features and institutional policy access opportunities of the domestic civil society in each national case, and that think tanks should be analytically understood as the allies of, rather than competitors to, the older, established forces in civil society.
\end{abstract}

Keywords Think tanks - Civil society regimes · Corporatism $\cdot$ Sweden

Pelle Åberg, Stefan Einarsson and Marta Reuter have contributed equally to this article.

Stefan Einarsson

stefan.einarsson@hhs.se

Pelle Åberg

pelle.aberg@esh.se

Marta Reuter

marta.reuter@statsvet.su.se

1 Ersta Sköndal Bräcke University College, Stockholm, Sweden

2 Stockholm School of Economics, Stockholm, Sweden

3 Stockholm University, Stockholm, Sweden

\section{Introduction}

One of the most visible worldwide developments in civil society in the last two decades has been the increasing proliferation of a new type of policy-oriented actor: policy institutes or "think tanks". Think tanks, usually defined in the literature as formally autonomous organizations that disseminate, or themselves produce, policy research (see Stone and Garnett 1998; Stone 2000; McGann 2007; Medvetz 2008, 2012), appear to be becoming ubiquitous in many policy arenas; their activities, as described in the literature, range from compiling and (re-)packaging academic research results to producing their own research inhouse, and from mere provision of facts and information to active promotion of ideological agendas and political viewpoints. They have been characterized in the literature as "switchboards" through which epistemic communities are connected, and as "universities without students" (Weaver 1989), but also, perhaps more sceptically, as "dealers in second-hand ideas" (Stone 1996). The think tank label itself is today increasingly seen as a powerful discursive tool used by organizations to position themselves at the crossroads of academia, politics, media and business (Medvetz 2012).

Until the 1990s, think tanks were widely regarded as a typically US American phenomenon produced by the unique institutional traits of the American political system and culture (e.g. Stone 1996). In recent decades, however, the global proliferation of these organizations has led to a growing scholarly interest in them also in other national contexts (e.g. Stone and Denham 2004; Pautz 2012; Kelstrup 2016). In this context scholars have, among other things, noted the importance of a country's wider institutional architecture for the size, character and influence potential of its think tank population. Such institutional 
architecture is often conceptualized in terms of the character of a country's policy system, or, more recently, its "knowledge regime" (Kelstrup 2016, 2017). Few studies have, however, analysed think tanks specifically as a civil society phenomenon, or linked the proliferation of this relatively new type of actor to the transformations of civil society structures and of the prerequisites for the participation of civil society actors in policy-making.

This article sets out to do just that. The argument that we put forward here reads as follows: because of the ideational and ideological character of their activity, think tanks are essentially civil society actors (the production of ideas and ideology being chiefly the function of civil society, as we will elaborate on later in the article). The scope of the expansion of think tanks in a society should therefore be seen as related to the broader institutional make-up of a country's civil society and to the character of the interest representation system with respect to policy access for civil society actors, rather than only (and more narrowly) to the characteristics of the political system or the knowledge regime.

To substantiate this argument, we discuss the relatively young think tank field in Sweden and position the emergence and recent growth of this field in relation to the wider transformation processes of the last decades in Swedish civil society. Because of the previous existence of established and institutionalized channels for policy influence for civil society actors, we suggest that Sweden might be regarded as a least-likely case (Levy 2008) in terms of the probability for think tanks to emerge as a visible policy actor. The tradition of involving civil society actors in policy-making has a long standing in Sweden-a country which has been characterized by international scholars as a prime example of (neo)corporatism (Lijphart and Crepaz 1991; Siaroff 1999), and with a civil society primarily geared towards political advocacy and interest representation (Salamon and Anheier 1998; Wijkström 2012). During most of the twentieth century, the Swedish policy-making system was institutionalized around a number of established, large membership-based civil society organizations who, because of their (internationally) very high membership rates, commanded considerable resources that could be invested into policy research units, sections or departments. Many of these organizations were heavily involved with the state's corporativist structures, exercising considerable influence on public policy-making in their respective fields (see, for example, Rothstein 1992; Micheletti 1995).

In this sense, the Swedish "policy advice market" could be regarded as mature and saturated, with few openings for new actor types. Yet, since the turn of the Millennium, Sweden has experienced a very steep increase in the number of think tanks, with over three quarters of the currently operating think tanks having been established only in the last 20 years. What can this sudden expansion be attributed to? In line with Levy's (2008) Sinatra-derived argument for the merits of the least-likely case research design- "if it could happen here, it can happen anywhere"-we suggest that shedding light on this unlikely Swedish development will tell us a lot about the institutional forces behind the more general rise of the think tank phenomenon outside of the North American context.

In principle, any of the other Scandinavian countries could also have served as an empirical case in our study. These countries share with Sweden both similar institutional development trajectories and models, and a recent experience of a relatively sharp increase in the number of think tanks. Sweden is however, in our eyes, particularly suitable as a case in relation to the theoretical argument that we want to make. Think tanks are a recent phenomenon in all of Scandinavia, but their numbers are relatively higher in Sweden than in its neighbour countries, and the increase in these numbers started earlier there (Blach-Orsten and Kristensen 2016). Moreover, as Sweden is usually singled out in international research as the prime example of the institutional models that are at the centre of our argument, we believe that using it as an illustration will make our argument more transparent and persuasive for an international audience.

Empirically, the article sets out to do two things. Firstly, we provide an overview of the burgeoning Swedish think tank field, which hitherto has not been studied in its entirety. We discuss the defining characteristics of this field and of the actors populating it, and, in the analysis, we situate them against the background of the institutional transformations in civil society that we argue have shaped this emerging field. Secondly, we use these recent transformations as a backdrop against which we seek to interpret the self-understanding and self-image of Swedish think tanks. In order to capture the latter, we look at the development of the think tank field in Sweden through the eyes of interviewed think tank executives. At the core of our interest here are the think tankers' own perceptions of the institutional landscape in which their organizations are embedded, and of the factors to which they themselves attribute the unexpected emergence of a "niche" for think tanks in Sweden.

The two empirical questions that we pose are thus: what does the think tank landscape look like in Sweden? And, how do think tank executives understand their organizations' roles and positions in society in relation to the recent institutional transformations in Sweden? At a more general, theoretical level, the aim of the discussion is to draw scholarly attention to the role of the character and structure of civil society, and of the interface between civil society and the public policy system, in creating prerequisites for 
the emergence of the think tank as a policy actor in a nonAnglo-Saxon, (post)corporatist setting.

\section{Think Tanks and Their Institutional Environment}

Although think tanks today are globally ubiquitous and can be found in most countries (e.g. McGann 2018), the origins of this type of organization are unmistakably North American. Since, as mentioned above, the main function of think tanks is usually conceptualized in terms of policy advice, the literature relates the prevalence of the think tank phenomenon in the USA to the unique institutional traits of the American political and policy system. The most commonly mentioned of these traits are the division of powers between the president and Congress where a strong mandate for the legislators to put forward policy proposals of their own creates a large audience for policy research; relatively weak political parties which do not play a major role in policy research development, thereby leaving a niche for other types of actors in this field; and the relative permeability of the public administration (e.g. Weaver and Stares 2001). Another aspect of the American institutional architecture is the strong tradition of foundation-, corporate- and individual-based philanthropy that constitutes a major source of funding for independent policy research (Weaver 1989).

Students of the role of think tanks in the US have long contended that taken together, these institutional traits have created a unique niche for external policy-oriented actors, explaining the rise and prominence of think tanks in the USA and their relative absence in other industrialized democracies (particularly those with parliamentary systems), which lack the above-mentioned conditions and appear to generate few if any entry points for external policy actors. However, since the 1990s, the number of think tanks have increased dramatically across the world, including in democracies with parliamentary systems such as the Scandinavian countries (see, for example, BlachOrsten and Kristensen 2016), but also at the international and supranational (particularly EU) level (Kelstrup 2016; Rastrick 2018). Accordingly, there is an increasing realization that the proliferation of these organizations needs to be treated as a global, rather than a particularly American, phenomenon, but also that there is a need for a more nuanced understanding of the institutional prerequisites for the emergence of a "niche" for think tanks in a country (cf. McGann and Johnson 2005).

Based on the Swedish case, we argue that such understanding requires giving attention to think tanks not only as policy actors, but also-or even foremost-as actors in civil society. The nature of think tanks as an essential part of civil society has been notably stressed by McGann and
Weaver (2002) who notes that the proliferation of think tanks, among other things, is related to the character of a country's civil society. However, their discussion is posited at a very general level, distinguishing only between open (democratic) and less open (authoritarian) societies and stressing above all the institutional prerequisites for the emergence of policy debate and policy advice that would be independent from the government. While useful in the context of democratization processes, it is less helpful for the analysis of the institutional factors that might facilitate the emergence of think tanks in established democracies such as Sweden.

There is little evidence to support the assumption that the institutional architecture of Sweden has become more similar to that of the USA regarding such aspects as the constitutional rules regarding the division of power or the openness of the public administration. On the other hand, as we will discuss below, Sweden has experienced (and is still experiencing) a significant transformation in two dimensions which, as we argue below, determine how the ideational and ideological functions performed in and by civil society are organized. In these two dimensions, Swedish society has taken a number of small, but important steps in the direction of a more liberal, pluralist system resembling that of the USA. In the next section we elaborate on these dimensions.

\section{Civil Society and Policy-Making —A Theoretical Framework}

In this article, we proceed from a neo-Gramscian-inspired perspective that highlights civil society's normative, ideational and discursive functions and the fundamental striving of civil society actors to shape and mould the public's perceptions of what constitutes the public good (cf. Reuter et al. 2014). Such functions include the generation and dissemination of, as well as mobilization around, ideas and ideologies, and can be, in turn, expressed through a number of voice and service related activities such as advocacy and interest representation on the one hand (voice), and participation (on religious or other ideological grounds) in welfare production on the other hand (service). We argue that the concrete organization of these ideational functions in a society is context-bound, and contingent on at least two factors: the overall character and structure of civil society, and the character of the public policy system with respect to the role of civil society actors.

When it comes to the first of these factors, the concept of civil society regimes (Salamon and Anheier 1998; see also Enjolras and Sivesind 2009; Salamon et al. 2017) has come to be widely regarded as a useful tool in making systematic international comparisons of national civil societies. 
Salamon and Anheier (1998) suggest that civil societies in the industrialized part of the world can be divided into four categories, or "regimes", two of which are particularly relevant here. In the liberal regime, restricted government social welfare spending translates into a large nonprofit sector, with a tax system that rewards philanthropy, welfare service and charity-related activities, and at the same time punishes involvement in political advocacy. In the SocialDemocratic regime, on the other hand, extensive government-provided social protection leaves little room for welfare service-producing nonprofits, and the organized civil society acquires a distinctly advocacy ("voice") oriented profile. In countries belonging to this latter category, the welfare-oriented nonprofit sector as well as charity and philanthropy will be relatively negligible, and civil society is instead dominated by a dense network of strong member and volunteer based advocacy, interest and recreational organizations.

The concept of civil society regimes is useful here as it enables us to make the distinction between service-oriented and voice-oriented civil societies; a distinction that is highly relevant for the organization of the ideational functions of civil society actors. It is reasonable to assume that in a strongly voice-oriented civil society, particular channels, platforms, vehicles and instruments for ideology production and policy formulation, but also more generally for mobilization around certain ideas, values and goals, will have developed and over time become institutionalized within the existing movements and organizations, leaving little room for external actors to perform these functions. Conversely, in a more liberal and service-oriented civil society regime, the very heterogeneity of civil society and the relative lack of comparable stable institutional structures that would support long-term policy development and ideological mobilization within the existing movements and organizations, will be more conducive to the emergence of independent organizations particularly oriented towards policy research and ideology production.

The second institutional dimension that we believe to be central to the ideational functions of civil society is the configuration of the policy-making system in a country with respect to the role of civil society actors and the type of access to policy-making awarded to them. Here, the distinction between the (neo-)corporatist and the pluralist system of interest representation ${ }^{1}$ (see, for example, Williamson 1985) is useful. In the pluralist system, the policy process is usually described as being relatively open to different interest groups that compete to advance their own

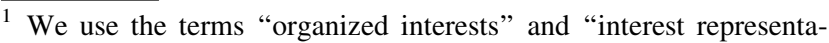
tion" in a wide sense here, referring both to organized pursuit of selfinterests and to advocacy on behalf of others or on behalf of the public good.
}

interests and points of view. The state acts as a relatively neutral arena for mediation between different interests and is, at least in theory, not supposed to a priori favourize any of them (Dahl 1961). An internal system of checks and balances is thought to make it difficult for one civil society actor or group of actors to dominate or take control over the policy on a given issue.

The corporatist system, on the other hand, is characterized by a close and mutual benefit-oriented relationship between (certain) actors in civil society and the state. Here, the government grants access to the policy-making process to certain (types of) civil society organizations, which in return lend legitimacy to that process and induce stability into the system, preventing the risk of the government and powerful civil society actors finding themselves at odds with each other (Lundberg 2014; also Schmitter 1981; Molina and Rhodes 2002).

The distinction between corporatist and pluralist systems of interest representation enables us to distinguish between two different roles awarded to civil society actors in the public policy system: the role of "insiders" with institutionalized channels of access, or the role of "outsiders" that need to use various strategies to make their voices heard over the voices of all other competing interests and ideologies. It may be assumed, we argue, that the former reduces, and the latter increases the incentive for "external" policy experts_-such as think tanks - to emerge and attempt to influence public policy.

In Fig. 1, we illustrate the dimensions we have now discussed. The figure also helps to show what we bring with us into the analysis of the Swedish think tank field.

The combination of these two dimensions-civil society regime and system of interest representation-allows for a relatively nuanced picture of a country's institutional

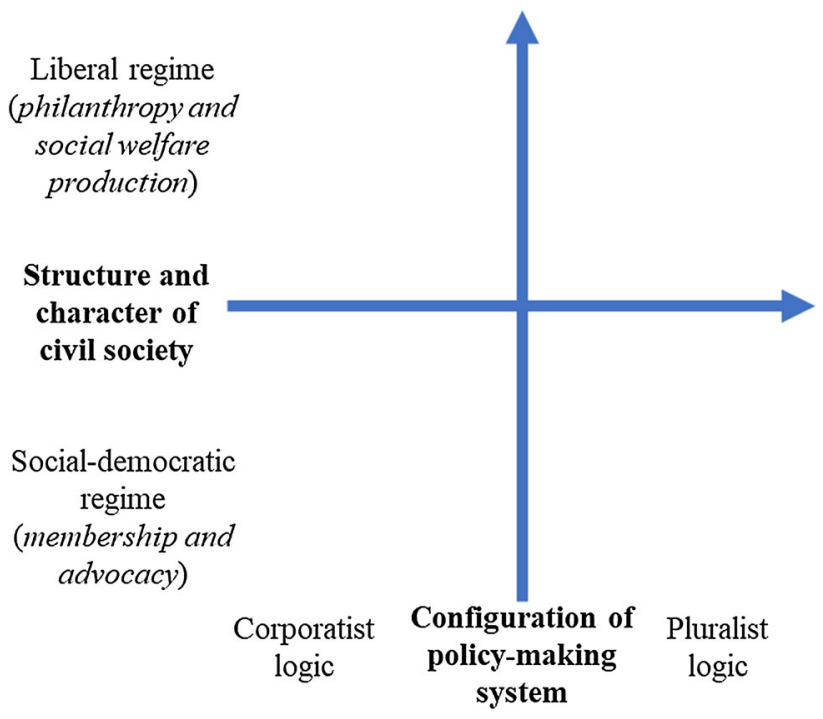

Fig. 1 Institutional dimensions of civil society functions 
landscape with regard to the way in which the ideational and ideological functions of civil society and its actors are organized. Our theoretical proposition is therefore that these dimensions will also play a central role when it comes to the potential for the emergence of an institutional niche for think tanks in a society, as these organizations are inherently ideational and/or ideological actors. We substantiate this argument with the empirical example of Sweden, and below we briefly discuss these two dimensions in the Swedish context.

\section{Civil Society and Policy-Making in Sweden}

Swedish civil society has during the last hundred years been internationally noted for three things: it has been very vibrant, with an unusually strong emphasis on active membership; it has been oriented towards advocacy, interest representation and leisure, i.e. voice, rather than welfare service provision (Lundström and Wijkström 1997; Salamon and Anheier 1998); and it has been embedded in one of the most corporatist systems of interest representation in the world (Lijphart and Crepaz 1991; Siaroff 1999).

The strong voice orientation of Swedish civil society puts it squarely within Salamon and Anheier's SocialDemocratic regime. As the provision of social welfare has been the near-monopoly of the state for most of the twentieth century, welfare-oriented nonprofit organizations have led a very marginal existence in Sweden. Instead, the Swedish associational life has to a very high extent revolved around the so-called popular movements (folkrörelser): the temperance, free-church, agricultural, labour, women's and sports movements, and later also the environmental movement (Elvander 1966; Micheletti 1995; Götz 2003). These movements - characterized by, among other things, an active mass membership, internal democracy based on a three-level representative federative structure and focus on advocacy and representation-had in the early to mid-twentieth century succeeded in more or less replacing the earlier, charity-oriented forms of civic association, and came to dominate Swedish civil society for several decades, giving it a particularly strong voice profile (see Trägårdh 2010; Wijkström 2012). ${ }^{2}$

From the early twentieth century, the movements more or less permeated the structures of the Swedish state, with their organizations having in many cases achieved formal representation in various public administration bodies even before their individual members obtained the right to vote,

\footnotetext{
2 The popular movement format in fact became so dominant in Sweden during the twentieth century that most membership-based organizations in other fields also self-identified as "movements" and organized themselves according to the movements' signum federative structure (cf. Micheletti 1995; Åberg 2015).
}

and thus enjoyed the status of the "preferred partner" of the government (Götz 2003: 43). The relationship between the state and civil society became still closer during the heyday of the Swedish welfare state in the mid-twentieth century (Rothstein 1992; Micheletti 1995), with the SocialDemocratic state lending political legitimacy as well as financial and structural support to the popular movements and their organizations.

The intimate involvement of popular movement organizations (but also other organized interests such as employers' organizations, who incidentally are organized in the same way as the popular movements) in the development and implementation of public policy has been central to the so-called Swedish model (Elvander 1966; Rothstein 1992) and to the relationship between civil society and the state in Sweden. Several different channels for this involvement have existed, of which the following three are usually seen as most important: (a) the systematic inclusion of civil society actors in the government commissions frequently employed in the early stages of the policy process; (b) the long-established government practice of sending out policy proposals for review to a wide range of societal actors including CSOs; and (c) the mandatory (until the early 1990s) inclusion of CSOs in the laymen boards of public agencies (Lundberg 2014). These and other access channels have for a long time ensured that the state and civil society (primarily represented by the popular movements) in Sweden have lived in something approaching a symbiosis, with the border between the two spheres sometimes being less than clear.

The long-term dominance of the popular movements in Swedish civil society has meant that the movements have been able to function as the de facto primary source of political ideas in the Swedish public debate and public policy processes in many fields. They have relied on a large and active membership and resource-rich secretariats for ideological development and on an internationally unique, very well-developed system of movement-affiliated adult education institutions, for consolidation and dissemination of their ideas (see von Essen and Ảberg 2009; von Essen and Sundgren 2012). The fact that some of the established Swedish political parties have their historical, ideological and/or organizational roots in one or the other of the movements (Micheletti 1995), combined with the abovedescribed corporatist public policy system, has meant that there has been an abundance of institutional channels through which the movements have been able to provide the public policy processes with ideational and ideological content.

Today, however, the above-outlined image of Swedish civil society and its relationship to the state, while still at least partly alive in the mind of the international civil society scholarship, no longer holds entirely true. Since the 
1990s - a decade marked by a financial crisis, deregulation and liberalization of the economy, and Sweden's entrance into the European Union-the institutional civil societystate nexus has begun slowly evolving away both from the Social-Democratic civil society regime and from the corporatist policy system, increasingly infusing these models with more liberal and pluralist elements (Blom-Hansen 2000; Öberg et al. 2011; Wijkström 2011, 2017). To be sure, it is not a question of them being replaced by other models; however, existing research indicates a tendentious shift or movement in the direction away from one idealtypical position and towards another one, as indicated by the dotted line in Fig. 2.

The development away from the traditional corporatist model of the twentieth century and towards a more liberal, pluralist model has been extensively debated in Swedish political science over the last thirty years (e.g. Lewin 1992; Hermansson et al. 1997; Rothstein and Bergström 1999; Christiansen et al. 2010). The shift has meant, among other things, that the key channels for institutionalized civil society access to policy-making appear to be decreasing in overall importance, at the same time as phenomena such as lobbying (Naurin 2001), participatory forums, dialogues and formal government-voluntary sector agreements (Reuter 2012; Gavelin 2018), and informal policy networks (Hysing 2010) are gaining visibility and weight. During the same period, the character, structure and composition of civil society itself have started to shift, with the segments of civil society focused on provision of welfare services, philanthropy and social entrepreneurship growing at a considerable pace, and the segments dominated by the popular movements and associated with voice- or advocacy functions experiencing relative stagnation (Lundström and

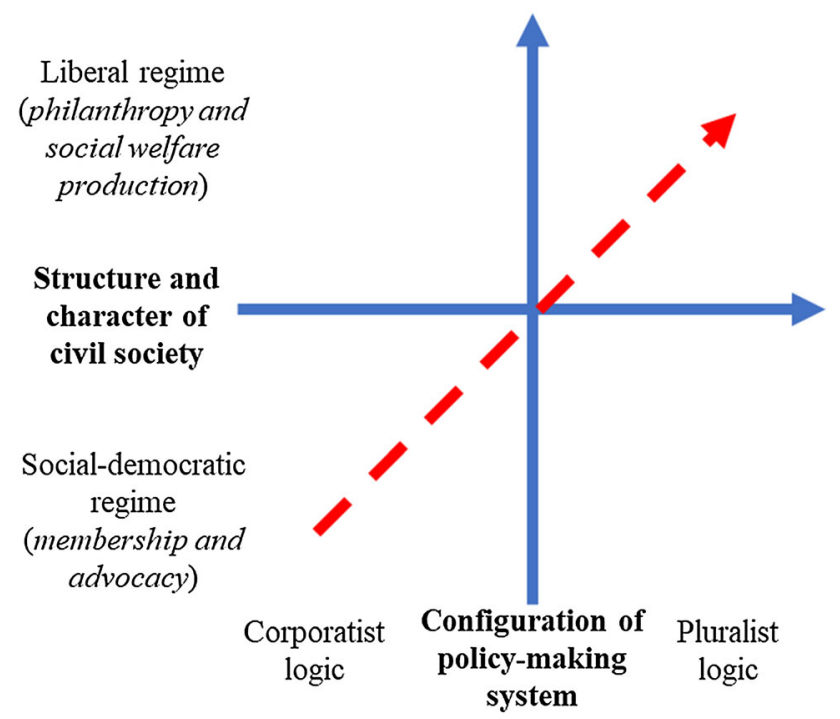

Fig. 2 Changes in civil society and the policy-making system in Sweden
Wijkström 1997; Wijkström and Einarsson 2006), even if civil society's role in the provision of welfare in Swedish society still is limited (Sivesind 2016; von Essen 2019). Changes in Swedish civil society can be further exemplified with how one of the characteristic pillars of the Swedish popular movement tradition, active individual membership (Einarsson and Hvenmark 2012), has decreased in overall numbers (although remaining at a very high level by international comparison), indicating a detachment of popular engagement from the role of being an active member in favour of more focus on the role of volunteers, which also is part of the development towards less focus on advocacy or voice and more on service provision (von Essen 2019). These developments, which have also to varying extents been observed in the other Nordic countries, have been construed in earlier research as constituting a break with the popular movement tradition (Selle et al. 2018). As we will see in the empirical discussion, these recent transformations are in fact also very central to the way in which Swedish think tankers themselves understand the emergence of an institutional space or niche for their own organizations.

\section{The Study: Methodology and Materials}

The discussion in the empirical section of this article is based on an empirical overview of the emerging think tank field in Sweden, and on interviews with the executives of the identified think tanks. As "the think tank" is an empirical, rather than a theoretical concept, the issue of where to draw the definitional line around this field (cf. Medvetz 2012) and thus between think tanks and other types of organizations (e.g. traditional academic research centres or interest groups) is analytically tricky-something that has already been extensively discussed in the existing literature. For the purpose of this first mapping in the Swedish context, we have tentatively chosen a relatively wide definition of what a think tank is: a formally independent organization that in different ways works with (produces, packages and/or disseminates) policy-relevant research, with the intention for the results to be used for policy and/or political purposes, by itself or other actors. This definition is in line with most existing international research (e.g. Stone and Garnett 1998; McGann 2007; Medvetz 2008, 2012; Bertelli and Wenger 2009).

It could of course be argued that there is nothing new in itself about the production and use of research for policyrelated purposes. What is new, however, at least in the Swedish context, is the rise and proliferation of entire organizations which perform an activity that previously has been mostly undertaken in-house by different policy and civil society actors themselves. By limiting our definition 
to "formally independent" organizations, we focus therefore on actors who exist specifically with the purpose or mission of performing this particular activity. This means that we exclude, for example, pure university-based research institutes that produce basic, rather than policyoriented, research, but also internal, policy research producing investigation units in larger organizations such as political parties, trade unions, state agencies, corporations, and so on.

With the above definition as a departure point, we initially identified 38 organizations currently active in and around what we define as the "space of think tanks" (cf. Medvetz 2012) in Sweden. ${ }^{3}$ Six of them turned out to be defunct, and a further seven did not agree to our interview request, alternatively did not respond at all. This means that our overview considers 38 organizations whereas the more in-depth part of the analysis is based on interviews with, and internal documents from, 25 of these think tanks. The 25 interviewed organizations include all the larger think tanks when it comes to revenue, turnover and number of full time employees (the majority of the organizations that declined our interview request alternatively did not respond have none or one employee), as well as representing the different categories of think tanks which we will expand upon below. We are thus fairly confident that our interviews capture the breadth of the Swedish think tank landscape.

Documents (such as annual reports and website information) have above all been important in the overall mapping of the think tank space, while the interviews are the main source used in our discussion of the think tanks' own perceptions of the institutional and societal transformations that have created a niche for them as a new type of actor in Sweden. The executives of the studied think tanks are interviewed in a double capacity: both as respondents, conveying their own notions of their organizations' role(s), and as informants or experts, providing a unique insight into the development of the Swedish think tank field and its relations to other types of actors in civil society. For these purposes, the executives and their perspective are important since they are the ones heading the day-to-day activities of the think tanks.

The executives have varying backgrounds, which may partly be a result of the multitude of activities and legitimacy bases of think tanks. Thus, some of them have had a long-term engagement in the political establishment, for instance in the capacity of holding high-ranking positions in political parties. Others hold professor titles from academic institutions and yet others have a background in the media world as journalists, publishers, etc. We believe that

\footnotetext{
${ }^{3}$ Note that other authors, using other definitions and criteria, have arrived at different figures, e.g. McGann 2018.
}

this broad experience of the executives from the spheres adjacent to the think tank field gives them a unique insight into the wider institutional environment in which their organizations are embedded, and thus makes them particularly appropriate as respondents in our study.

Each interview was between one and two hours long and they were all recorded and transcribed in verbatim, and subsequently analysed using NVivo and thematic analysis with an abductive approach (Bazeley and Jackson 2013; Saldana 2013). The quotes used in the article have all been translated by the authors and in certain cases also edited for clarity.

\section{The Think Tank Field in Sweden}

In this section, we present a broad overview of the Swedish think tank landscape. What does this landscape look like? One of the premises of this article-that think tanks have become a more prevalent type of actor in Swedish society-is evident from the sheer number of such organizations that have been founded in recent years. The first of the 38 identified Swedish think tanks was launched at the end of the 1930s, and subsequently only one or two new such organizations emerged per decade until 1999. However, from the year 2000 onwards 29 new think tanks have been founded. While these are naturally small figures in comparison with countries such as the USA or the UK, Sweden has also a comparatively smaller population-approximately $10 \mathrm{mln}$ inhabitants-which makes this increase a highly visible one in the Swedish organizational life. This development is graphically illustrated in Fig. 3.

However, these numbers alone are not enough to gain an understanding of the organizations inhabiting this landscape. Hence, we need to dig a little deeper and look at a few organizational attributes.

The size of Swedish think tanks, in terms of, for instance, revenues, turnovers and number of employees, varies considerably. There are think tanks with basically no revenue or turnover, mainly making use of voluntary work,

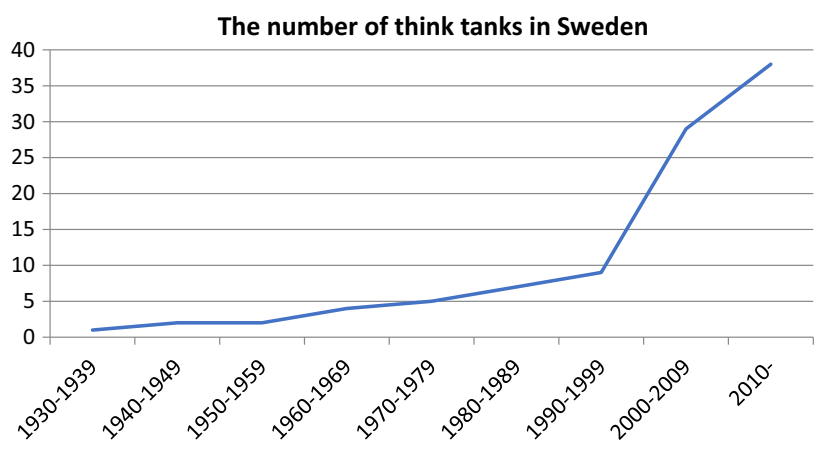

Fig. 3 The number of think tanks in Sweden over time 
and there are a few with revenues of around 40 million SEK (almost 3,5 million Euros). Since some think tanks are based on voluntary work, there are those who have no employees at all, but among those that do the size of that staff varies between one and approximately 90, with the majority having between one and ten employees.

The Swedish think tanks are furthermore quite diverse when it comes to the type of principal and the ideologies and interests that are represented and advanced through the activities of the organizations. Seven of the 38 organizations studied exhibit connections to business interests, and an additional four to a neoliberal ideology, promoting issues such as free enterprise and aiming to improve conditions for entrepreneurship and small businesses. We also find four think tanks that are connected to the political left, to trade unions and the workers' movement. Several of the identified think tanks have also more or less explicit connections to political parties. We find such links between think tanks and the Social Democratic Party (three), as well as the Christian Democratic Party (one) and the Green Party (one). A couple of the think tanks have their primary connections to the academic world in the form of universities. Two have religious ties with a Christian background.

Eight of the organizations, furthermore, are most accurately described as politically or ideologically independent. Although most of the studied think tanks assert "independence" or "autonomy" (also in the cases where they formally adhere to a certain ideology), these eight stand out in that they do not explicitly endorse or claim to represent any clear ideology in terms of politics, religious beliefs or similar values. Instead, several of them are focused on single issues, such as, for example, preventing the use of tobacco. These few neutral think tanks are often mid-sized or large and have employees with a background in research.

So, what do all these think tanks do? The studied organizations all engage in a variety of activities that are commonly associated with this type of actor, such as organizing seminars and debates, and publishing reports, articles and books. The extent to which they actually produce their own research or simply repackage and use findings from other sources varies, however, not least depending on the available resources. The four largest think tanks stand out as being significantly more active in more expensive activities than the others, together producing more than 300 seminars, close to 200 reports and 40 books in one year. While they have surfaced at different points in time, all four of them were founded well before the think tank boom of the last decades. These four think tanks also have among the highest revenues and, interestingly, all four have the Confederation of Swedish Enterprise (Svenskt Näringsliv, Sweden's largest business federation) as one of their important funding sources. Thus, the influence of business interests on the Swedish think tank landscape is quite striking.

To summarize this part of our findings, the development of the Swedish think tank field has been characterized by a sudden and fast growth, but most of this expansion consists of small-to-mid-range actors. The field is fairly diverse with regard to standard organizational characteristics and the type of principal and ideology behind the organization. What can be said is that the Swedish think tanks founded up until 1999 are the largest, and that they are either connected to the Confederation of Swedish Enterprise or politically or ideologically independent. The pattern for think tanks founded in the new Millennium looks rather different, with almost all of them being small or mid-sized and several of them being connected to organizations on the left of the political spectrum or to progressive social movements. Importantly, our overview also demonstrates that most of the identified think tanks are in different ways connected to key actors and forces in Swedish civil society: popular movements, political parties, organized interests (primarily business interests), etc.

\section{Think Tanks in a Changing Institutional Landscape}

One of the questions that we address in our study concerns what executives of Swedish think tanks themselves perceive as the factors behind the emergence of a "niche" for them in Sweden. How do think tankers understand the role and position of their organizations in society in relation to the broader institutional environment?

Three overarching themes concerning this topic are discernible in the empirical material. All three relate the emergence of think tanks to broader societal transformations that the respondents see as having created both the need and the space for their own organizations in the Swedish institutional landscape. Below we briefly present these themes.

\section{Changing Role of Popular Movements}

The first theme relates to perceived transformations in the internal processes of the popular movements and political parties, and the loss of both political initiative and political influence on the part of these traditional civil society actors. There is a strong perception among the respondents that these transformations have created a need-or an opportunity-for think tanks, as (at least in theory) independent actors, to do things that previously were done within political parties and popular movements. The emergence of think tanks is portrayed as a solution to the crisis that the movements and to some extent also the 
established political parties are going through. Several of the interviewed executives also speak about a shift in the traditional character of voice production in Swedish civil society:

People no longer believe that the old ways to create political proposals and conduct political debates are working... It used to be that issues where brought forward through the popular movements but now they are brought forward by the think tanks. (Interview, Tankesmedjan Tiden)

In a similar vein, one respondent half-jokingly states that think tanks should be seen as the new popular movements, and that they, by virtue of being new, are seen as free-thinking and independent and are therefore not met with the mistrust that (according to this respondent) other parts of civil society are increasingly facing.

The interviewees point to several different developments that in their view work against the popular movements as "voice bearers" in society and in the public policy processes and at the same time create favourable conditions for think tanks. One such development is the shift in how people choose to channel their societal and political engagement. One respondent reflects on this in the following way:

Quite a lot of people today do not involve themselves in politics or in the popular movements, but they are passionate about changing society in some way. Ten, fifteen or twenty years ago they would be engaged in one of the narrower issue organizations like Greenpeace or Amnesty but even that kind of engagement is fading. I think it is because they see that the issues in reality are broader than that... And there I believe think tanks can play a part. Because it is about politics, but not party politics; we are not like the old popular movements, but we are part of the public conversation. And previously you worked within the old popular movements if you wanted to do these things, but you don't do that anymore to the same extent. (Interview, Global Utmaning)

Echoing this, several respondents point to the fact that there have been changes not only in the organizational structures of Swedish civil society, but also in individual popular engagement. In the eyes of the interviewees, the increasing failure of the more traditional civil society actors such as the popular movements and the parties, but also more established "non-movement" organizations to attract members and reach out to the general public affects negatively their possibility to exercise influence in the public policy arena. This again opens up, in the eyes of our respondents, a space for a new type of policy-oriented civil society actor-one whose legitimacy and credibility in the policy arena are less dependent on high membership figures and more on other types of resources.

\section{Changing Prerequisites for Traditional Civil Society Actors in the Policy System}

The second theme emerging in the interviews concerns the recent decades' shift in the way policy-making is structured in Sweden. The decline in the use of government commissions and referrals (i.e. review of legislation proposals by influential CSOs) as a channel for impacting policy is a salient theme in the accounts of our respondents. Several interviewees contend that this decline has led to a diminished influence for the Swedish popular movements and other established forces in Swedish civil society, as this system has been one of their main power bases within the corporatist system. According to some of the think tank executives, this development has led to less consensus and more fragmentation in public policy-making, since the corporatist system previously enabled different interestbased organizations, researchers, experts and other stakeholders to work together on particular issues for longer periods of time.

...previously, you had commissions running over longer periods of time where researchers, experts and organized interests were involved, and that created consensus [around larger political issues]...but you don't have that anymore, and that's why you don't have the same consensus. (Interview, Global utmaning)

In the interviews, the transformation of the interest representation system is described as a shift from a situation where all stakeholders are invited to create a joint report together, for example in the framework of a governmental commission, to a more competitive situation where all involved actors create their own reports and compete for the attention of the public, the media and in the "policy market". This has, in the eyes of the interviewees, not only led to an increased space for think tanks by opening up the policy process, but also created a need for them and their services. According to the respondents, one of the main reasons for popular movements and other established civil society actors to create think tanks has been to find a new channel for the production and dissemination of policy suggestions, that would (at least partly) fill the vacuum created by the decline of the commission and referral system.

At the same time, some of the interviewees point out that even as this transformation has created more space for new actors to enter the policy process, it has also further increased the demands on traditional CSOs concerning professionalizing their interaction with the state, for 
example, their reports and referral responses. This kind of pressure for professionalization is according to our respondents' one of the major reasons for popular movements to establish think tanks:

There is pressure from government agencies and other grant givers that you need to have researchers involved and have our work academically evaluated... [these demands] mean that you have to professionalize this voluntary work...it is not just this voluntary organization [saying]: we want to do this, this is exciting, but you have to adapt to very different demands. The work has to be professionalized and I think this definitely strengthens this trend towards think tanks. (Interview, Tobaksfakta)

Another respondent continues along this line and states that the terms of politics have changed and become more technocratic and less ideological:

...this is a bit of the same... evidence-based politics. The need to hide yourself behind a report [rather than] having a vision or conviction of your own... You need to have scientifically proven values in order to dare to stand for something. It is an expression of how cowardly politics have become. I can miss the visions in politics. (Interview, Futurion)

In the accounts of our respondents, the transformation of the system for interest representation concerns not only the choice of channels for influence but also the public understanding of politics and the role of, as well as the demands on, different types of policy actors. The shift in the types of arguments that are seen as legitimate in the public debate-from more ideological to more evidencebased, expert-generated and technocratic-has been, in their view, disadvantageous to the more traditional Swedish civil society actors, but has benefited think tanks which have a more technocratic and expertise-based profile.

\section{The Role of Communication Technologies}

Another development frequently mentioned by the respondents is the change of pace in the public debate and in the policy processes, due to the emergence of new communication and information technologies. As several respondents note, public and political debate works according to a different timeframe today than it did a hundred years ago when the organizational foundations of many of the popular movements were laid. The slow internal democratic debate cycle of the movements, revolving around, for instance, the annual member congress, is not seen as optimal for the era of instant communication where the debate is often driven on an hour-to- hour basis with the help of tools such as Facebook or Twitter.

This shift has, in the eyes of the interviewed think tank executives, radically changed the way organizations interact with their constituencies and with the general public, creating new demands when it comes to communication skills. Remarkably, while one might expect this to lead to the more traditional civil society actors lagging behind in this respect, some of the interviewees point to an opposite phenomenon: established organizations such as political parties and the popular movements focus according to them increasingly on communication and public relations activities centred on the social media, which leaves them with less time and resources for the less visible activities related to ideological development. This is, again, seen as creating a niche for think tanks to fill:

The Social-Democrats have around 100 employees but about 70 of them work with communication and no one works with research or inquiries. So there is no one who creates political content, and that is where we have our role. It is an effective way to influence the debate with rather small means. [Interview, Katalys)

Several of the respondents point in a similar way to a certain ideological stagnation of the parties and the popular movements, which in their eyes generates a need for someone else to step in and create "political content". At the same time, they see their own organizations as clearly benefitting from the recent decades' development in information technologies. A number of respondents point to the technological shift as having enabled think tanks to reach out to the general public and policy experts in innovative ways, and without prohibitive costs. When, thirty years ago, the conventional way of reaching a wider public would have been to publish books, magazines or organize seminars, digitalization creates new opportunities in this respect. Publishing books and reports is naturally much cheaper with print on demand, and such products can today also be easily distributed for free as PDFs through the internet. Seminars can be webcasted instead of-or in addition to-using large auditoriums, and it costs little to have recordings or podcasts of previous seminars available on the webpage. Social media, as some of our respondents point out, also makes it easier to target and reach new target groups and audiences.

\section{Analysis}

In the theory section, we outlined two dimensions that we see as particularly important for the way in which the ideational aspect of civil society activity is organized in 
society: the structure and character of civil society itself (operationalized as the civil society "regime") and the character of the policy-making system with respect to openness to influence from civil society. We argue that because think tanks are essentially ideational actors and as such a natural part of civil society, the potential for an institutional niche emerging for this type of organization will be to an important extent determined by a society's position in these two dimensions.

We find the Swedish case to be a compelling illustration of this argument. A remarkable finding from our study is the extent of the structural embeddedness of Swedish think tanks in wider civil society, a feature that is further underlined by the key role assigned to the popular movements in the narratives of the interviewed think tank executives. In the interviews, the respondents consistently use the previously hegemonic position of the popular movements in the Swedish policy arena as a rhetorical departure point for their reflections on the transformations that have created a niche for their organizations in the institutional landscape. Together with political parties, popular movements appear in their narratives as the given policy-producing actors in the Swedish policy arena, and the transformations that the respondents point to are consistently related to how they affect these two types of actors. The emergence of a niche for think tanks is clearly perceived by the think tankers themselves as a consequence of a change in both the role and position of, and the institutional prerequisites for, these more established, traditional idea and ideology producing civil society actors.

The themes that emerge in our material relate clearly to the recent two decades' institutional changes discussed earlier in this article: the gradual change in the character and composition of the Swedish civil society; and the gradual de-corporatization, leading the relationship between civil society and the state in a more pluralist direction. At the intersection of these two, a third trend appears in the interviews, pointing to an ongoing transformation of the ways in which the knowledge fed by civil society actors into political policy processes is produced and processed. Below we relate our empirical findings to the two dimensions of our analytical model and to the existing Swedish and international research in this area.

\section{Civil Society Regime}

As we have seen, the diminishing influence of the popular movements appears to be central to the respondents' understanding of the institutional environment relevant for their own organizations. In existing research, this development has often been associated with recent decades' gradual shift from civil society as primarily a site of "voice", i.e. advocacy, to civil society as-also-a potential producer of welfare services (cf. Reuter et al. 2012). Here, the hegemony of the popular movements is often seen as being challenged by the resurrection of nineteenth-century phenomena such as charity, philanthropy and social welfare-related volunteering, although in a new, more modern and Anglo-Saxon-inspired form (Wijkström 2017; Wijkström and Einarsson 2018), with the Social-Democratic civil society regime thus increasingly acquiring elements from the liberal regime.

For our argument about the institutional space for think tanks depending on the structure of civil society, the increasing welfare-oriented component in the Swedish voluntary sector is less important than the transformation within the voice (advocacy) dimension itself. The need for channelling the voices of citizens and representing the diverse interests in society has naturally not disappeared. The interviews indicate that when it comes to advocacy, the development in Swedish civil society is understood by the actors in the field as entailing a move from the broad membership-based national federations towards a different type of more professional organization -with professionality signalling here values such as "flexibility", "effectivity", etc.

The gradual reorientation of civil society from being based on mass association to being oriented towards smaller, memberless and professional organizations, discussed in the literature by, for example, Wijkström and Einarsson (2006) and Papakostas (2012), is not unique for Sweden. Particularly the US American experience is illuminating here, as a similar development in the USA a few decades ago (e.g. Skocpol 2003) appears to have coincided with a major wave of think tank growth, as described by, for example, McGann and Weaver (2002) or Rich (2004). In both the Swedish and the international literature, factors such as new sources of financial support, innovative technologies for funding and advocacy, and new organizational forms, together with demographic changes (with increasing numbers of highly educated experts creating a broad constituency for professionally managed CSOs), are usually mentioned as the drivers behind the above-mentioned development (Berry 1989; Skocpol 2003; Garsten et al. 2015). These factors all appear in our interviews with representatives of Swedish think tanks.

A partly related issue concerns the changing pace of the public debate brought about by the developments in communication technology, which appear to have put the traditional voice-oriented civil society actors at a disadvantage. As the popular movements turn to a more reactive communicative stance, think tanks, with less dependency on, and daily contact with, movement constituents see themselves as offering the opportunity for more long-term ideological development and debate. The wider transformation in how the public debate is 
conducted, related to digitalization, new communication technologies, and the rise of social media, is apparently a factor that think tank representatives themselves see as benefitting the think tank as an organizational form.

The accounts given in our interviews point also to the increasing inability of the Swedish popular movements to attract new (particularly young) members and thus renew themselves demographically-which is also a phenomenon documented in extant literature on recent transformations of civil society, both in Sweden and elsewhere (Einarsson and Hvenmark 2012; Papakostas 2012; von Essen 2019; cf. Berry 1989; Skocpol 2003; Selle et al. 2018). Today, citizens appear to prefer to involve themselves in temporary campaigns on individual issues of interest to them, or temporarily join organizations that work on such issues, but as volunteers, not members-i.e. without having to get involved in what is perceived as the tedious and timeconsuming business of member democracy. In Sweden, this change in attitudes towards civic involvement presents an acute dilemma for the popular movements, whose legitimacy has traditionally rested, among other things, on the high membership numbers that allowed them to claim to represent large parts of the population (Einarsson 2011).

Significantly, the shift mentioned in the interviews concerning how people channel their civic engagement does not affect only ordinary citizens. It also speaks to recent research on the rise of so-called policy professionals (Garsten et al. 2015) — a caste of highly educated experts who often have extensive experience from politics, public administration or the academia, and a pronounced passion for particular policy fields or issues, but little interest in translating this passion into involvement in the slowmoving popular movements or political parties. Here, think tanks appear to offer an outlet for the interests and expertise of these professionals in ways that the more conventional, established civic institutions may have a hard time competing with.

\section{System of Interest Representation}

The transformations concerning the popular movements and other established actors in Swedish civil society, as they appear in the interviews, do not only relate to these actors themselves but also to their possibilities to influence policy-which links directly to the second dimension of Fig. 1 presented in the theory section.

As outlined earlier in the article, the corporatist system of interest representation has been one of the cornerstones of the so-called Swedish model for much of the twentieth century. The decreasing importance of this system and of the traditional policy influence channels for civil society is a strong theme in the accounts of our respondents. The think tank executives clearly link this development to a process of professionalization of politics, but also to the political society becoming less ideological, with policy actors striving to present themselves as relying on hard scientific evidence to a larger extent than before. According to the respondents, the decreasing usage of corporatist tools such as government commissions and referrals in combination with increased demands for technocratic rather than ideological content in policy advice have reduced the space for the popular movements in policymaking. It has also motivated the movements, as well as other established actors and interests in civil society, to seek new influence channels or tools in the new, increasingly pluralist, Swedish policy-making system.

The think tank, with its radically different approach to "doing policy advice" appears to provide such a tool. There are several reasons for why these organizations seem to be better equipped for the new, more "open" institutional environment in which Swedish policy-making takes place today. Organizational slimness and the lack of individual members (and thus slow and cumbersome democratic procedures), allow think tanks a higher degree of flexibility and independence in their interactions with the political decision makers. At the same time, their expertiseoriented image lends them (at least theoretically) certain legitimacy in an era where the messages of the mass movements are increasingly viewed by the public as expressions of ideology rather than knowledge, and of special, particularistic-rather than general, publicinterests.

Additionally, as we have already touched upon, think tanks benefit from a range of recent technological developments that enable relatively small actors to reach out to the wider public and policy-makers without having large resources. By using services such as YouTube or Twitter, and media formats such as electronically distributed PDFs instead of television and printed books and reports, such actors can diffuse their messages at a substantially faster pace and lower cost than what was possible three decades ago. Taken together, all these different factors appear to have made it attractive for the older, more established actors in Swedish civil society-which themselves are at a disadvantage now that the corporatist system that has favoured them is dwindling - to invest in creating new, smaller and more flexible policy-oriented organizations which can have a large impact on public opinion and policy processes at a relatively low cost.

The link between the transformations of the system for interest representation and the emergence of the think tank as a new policy actor is not new; it has been made in earlier empirical research, both regarding Scandinavia (e.g. BlachOrsten and Kristensen 2016) and in relation to other European countries with a corporatist past (Jochem and Vatter 2006; Karlhofer 2006; Fraussen et al. 2017). The 
accounts of our respondents appear also, on the surface, to confirm the earlier observation of, for example, Jochem and Vatter (2006) that the withering of the traditional corporatist channels for interest mediation and policy influence presents an opportunity for new types of policy actors to utilize the situation and try to position themselves in the inner core of political decision-making.

Our results point, however, to a factor that has so far not been noted in the extant literature. In the latter, think tanks in post-corporatist settings are usually portrayed as a new player in the policy arena that competes with and crowds out the older, more established actors. To a certain extent we can also see this view come up in our interview materials; for example the above-cited respondent who jokingly states that "think tanks are the new popular movements", conveying the idea of think tanks replacing an older, less effective or less modern type of civil society organization.

Yet, seen as a whole, the results of our study actually contradict this notion. Both our overview of the Swedish think tank landscape and the interview materials indicate that the studied organizations are very firmly nested within the existing, traditional civil society structures. There, they typically ally, rather than compete, with the more established actors within their own ideological and/or interest spheres. As shown above, most of the think tanks included in the study have either been founded by already existing civil society actors representing some form of organized interests, or are financed by such actors. They usually present themselves as belonging to either one of the "classical" popular movements, or more generally to some loosely defined sphere in civil society such as "the left" or the liberal-conservative (borgerligheten). Relatively many of them can easily be placed on the left-right scale traditionally central in Swedish politics and in the Swedish ideological landscape. Here, a distinctly cyclical pattern can be observed in the ideological development of the Swedish think tank field, with the oldest think tanks (established during the era of Social-Democratic ideological hegemony) clearly belonging to the centre-right ideological sphere, and many of the new ones (established during a period of a neoliberal and value-conservative turn in Swedish politics and public discourse) belonging to the centre-left.

We take this as an indication that in the Swedish context, think tanks function to a high extent as a new kind of influence channel for established movements and civil society forces-a new way of doing "voice"-rather than representing entirely new types of interests, ideological faultlines or cleavages in civil society. While the think tank as an organizational form may be a new phenomenon in the Swedish policy arena and civil society, and as such may be understood as institutionally competing with other, older organization types-for institutional space, resources, media attention, etc.- - this should not be confounded with the actual think tanks crowding out other organizations, particularly within their own movements or ideological spheres. Far from that, think tanks can rather be seen as a new tool in these actors' influence toolbox or mobilization repertoire- a new sort of megaphone if you wish, for the old messages, but apparently better suited for the postcorporatist era.

\section{Concluding Discussion}

Think tanks as a type of organization are becoming increasingly visible and assertive across the world, also in national contexts with no previous tradition of this kind of independent policy advise. Earlier research has primarily conceptualized think tanks specifically as policy actors, or as expertise-oriented actors in knowledge regimes. While their nature as civil society organizations has sometimes been acknowledged in the literature, little thought has previously been given to the implications of this for our understanding of think tanks' place and function in the policy arena, and of the factors behind their recent proliferation.

In this article, we have sought to address this gap. The purpose of our discussion has been to draw attention to two institutional environment dimensions that we argue shape the institutional space for think tanks: the character and structure of domestic civil society and the character of the institutional channels for interest mediation and policy influence.

We have sought to illustrate this argument with a discussion of the case of Sweden and the emerging field of think tanks there. As our study shows, the transformation of the Swedish civil society and of the system for interest representation in a more liberal, pluralist direction has in different ways entailed a relative weakening of the previously dominant, traditional popular movements and their organizations, forcing them to look for new channels for influencing policy and for new organizational forms that would be better suited to the new, more heterogeneous and technocratic institutional setting.

The two dimensions whose importance for the rise of the think tank phenomenon we have sought to highlight here provide in our view a useful lens through which the emergence of this new type of civil society and policy actor in non-US American settings can be analysed. The results from our study of the Swedish case indicate also that further research is needed on the links between think tanks and the more established forces in civil society that these organizations are in different ways connected to. While much of today's research on think tanks focuses on the 
ways in which they attempt to influence policy and on the extent to which they actually succeed to do that, issues related to the relationship between think tanks and those actors that establish and fund them and who benefit from their policy advise need to be explored if we are to gain a deeper understanding of the role of think tanks in our societies.

Acknowledgements Open access funding is provided by Stockholm School of Economics. The research discussed in this article has been conducted in the framework of a project financed by Ragnar Söderbergs Stiftelse (grant number E38/14). The authors wish to thank the two anonymous reviewers at Voluntas for their valuable comments, as well as express gratitude towards colleagues from the Stockholm Center for Civil Society Studies at Stockholm School of Economics, the Center for Civil Society Research at Ersta Sköndal Bräcke University College, the Department of Political Science at Stockholm University, the Center for the Study of the Organization of Politics at Södertörn University, as well as the participants in the ISTR (2018) and EGOS (2017) conferences for their constructive advice and feedback.

Funding This study was funded by Ragnar Söderbergs Stiftelse (grant number E38/14).

\section{Compliance with Ethical Standards}

Conflict of interest The authors declare that they have no conflict of interest.

Open Access This article is distributed under the terms of the Creative Commons Attribution 4.0 International License (http://crea tivecommons.org/licenses/by/4.0/), which permits unrestricted use, distribution, and reproduction in any medium, provided you give appropriate credit to the original author(s) and the source, provide a link to the Creative Commons license, and indicate if changes were made.

\section{References}

Åberg, P. (2015). Myths and traditions as constraints or resources? Path dependency and decoupling strategies among civil society organizations. Journal of Civil Society, 11(1), 19-38.

Bazeley, P., \& Jackson, K. (2013). Qualitative data analysis with NVivo. London: Sage.

Berry, J. M. (1989). The interest group society. Ill: Glenview.

Bertelli, A. M., \& Wenger, J. B. (2009). Demanding information: Think tanks and the US congress. British Journal of Political Science, 39, 225-242.

Blach-Orsten, M., \& Kristensen, N. N. (2016). Think tanks in Denmark-media visibility and network relations. Politik, 19(1), $22-42$.

Blom-Hansen, J. (2000). Still corporatism in Scandinavia? A survey of recent empirical findings. Scandinavian Political Studies, 23(2), 157-181.

Christiansen, P. M., Nørgaard, A. S., Rommetvedt, H., Svensson, T., Thesen, G., \& Öberg, P.-O. (2010). Varieties of democracy: interest groups and corporatist committees in Scandinavian policy making. Voluntas: International Journal of Voluntary and Nonprofit Organizations, 21(1), 22-40.

Dahl, R. A. (1961). Who governs? Democracy and power in an American City. New Haven: Yale University Press.
Einarsson, S. (2011). The revitalization of a popular movement: case study research from Sweden. Voluntas: International Journal of Voluntary and Nonprofit Organizations, 22(4), 658-681.

Einarsson, T., \& Hvenmark, J. (2012). Efter medlemskapet? In F. Wijkström (Ed.), Civilsamhället $i$ samhällskontraktet: En antologi om vad som stair på spel. Stockholm: European Civil Society Press.

Elvander, N. (1966). Intresseorganisationerna $i$ dagens Sverige. Lund: Gleerups.

Enjolras, B., \& Sivesind, K. H. (Eds.). (2009). Civil society in comparative perspective. Emerald: Bingley.

Fraussen, B., Pattyn, V., \& Lawarée, M. (2017). Thinking in splendid isolation? The organisation and policy engagement of think tanks in Belgium. In M. Brans \& D. Aubin (Eds.), Policy analysis in Belgium. Bristol: The Policy Press.

Garsten, C., Rothstein, B., \& Svallfors, S. (2015). Makt utan mandat: de policyprofessionella i svensk politik. Stockholm: Dialogos Förlag.

Gavelin, K. (2018). The terms of involvement: A study of attempts to reform civil society's role in public decision making in Sweden. Stockholm: Stockholm University.

Götz, N. (2003). Century of corporatism or century of civil society? The Northern European experience. In N. Götz \& J. Hackmann (Eds.), Civil society in the Baltic Sea Region. Aldershot: Ashgate.

Hermansson, J., Svensson, T., \& Öberg, P.-O. (1997). Vad blev det av den svenska korporativismen? Politica, 29, 365-384.

Hysing, E. (2010). Governing towards sustainability: Environmental governance and policy change in Swedish forestry and transport. Örebro: Örebro University.

Jochem, S., \& Vatter, A. (2006). Introduction: Think tanks in Austria, Switzerland and Germany-a recalibration of corporatist policy making? German Policy Studies, 3(2), 139-152.

Karlhofer, F. (2006). The long shadow of corporatism: Scope and limits of think tank activities in Austria. German Policy Studies, $3(2), 347-381$.

Kelstrup, J. D. (2016). The politics of think tanks in Europe. London: Routledge.

Kelstrup, J. D. (2017). Quantitative differences in think tank dissemination activities in Germany, Denmark and the UK. Policy Sciences, 50(1), 125-137.

Levy, J. (2008). Case studies: Types, designs, and logics of inference. Conflict Management and Peace Science, 25, 1-18.

Lewin, L. (1992). Samhället och de organiserade intressena. Stockholm: Norstedts.

Lijphart, A., \& Crepaz, M. M. L. (1991). Corporatism and consensus democracy in eighteen countries: Conceptual and empirical linkages. British Journal of Political Science, 21(2), 235-246.

Lundberg, E. (2014). A pluralist state? Civil society organizations' access to the Swedish policy process 1964-2009. Örebro: Örebro University.

Lundström, T., \& Wijkström, F. (1997). The nonprofit sector in Sweden. Manchester: Manchester University Press.

McGann, J. (2007). Think tanks and policy advice in the United States. Abingdon: Routledge.

McGann, J. G. (2018). 2017 Global go-to think tank index report. Philadelphia: Uni-versity of Pennsylvania.

McGann, J. G., \& Johnson, E. C. (2005). Comparative think tanks. Edward Elgar: Politics and Public Policy.

McGann, J. G., \& Weaver, K. (Eds.). (2002). Think tanks and civil societies: Catalysts for ideas and action. London: Routledge.

Medvetz, T. (2008). Think tanks as an emergent field. New York: Social Science Research Council.

Medvetz, T. (2012). Think tanks in America. Chicago: Chicago University Press. 
Micheletti, M. (1995). Civil society and state relations in Sweden. Aldershot: Avebury.

Molina, O., \& Rhodes, M. (2002). Corporatism: The past, present, and future of a concept. Annual Review of Political Science, 5, $305-331$.

Naurin, D. (2001). Den demokratiske lobbyisten. Umeå: Boréa.

Öberg, P.-O., Svensson, T., Christiansen, P. M., Nørgaard, A. S., Rommetvedt, H., \& Thesen, G. (2011). Disrupted exchange and declining corporatism: Government authority and interest group capability in Scandinavia. Government and Opposition, 46(3), 365-391.

Papakostas, A. (2012). De medlemslösa organisationernas tidevarv. In F. Wijkström (Ed.), Civilsamhället $i$ samhällskontraktet. En antologi om vad som stair pa spel. Stockholm: European Civil Society Press.

Pautz, H. (2012). Think-tanks, social democracy and social policy. Basingstoke: Palgrave Macmillan.

Rastrick, C. J. (2018). Think tanks in the US and EU: The role of policy institutes in Washington and Brussels. London: Routledge.

Reuter, M. (2012). Överenskommelsen som spegel och arena. In F. Wijkström (Ed.), Civilsamhället $i$ samhällskontraktet. En antologi om vad som stair pa spel. Stockholm: European Civil Society Press.

Reuter, M., Wijkström, F., \& Meyer, M. (2014). Who calls the shots? The real normative power of civil society. In M. Freise \& T. Hallman (Eds.), Modernizing democracy. Associations and associating in the 21st century. New York: Springer.

Reuter, M., Wijkström, F., \& von Essen, J. (2012). Policy tools or mirrors of politics. Government-voluntary sector compacts in the post-welfare state age. Nonprofit Policy Forum. https://doi.org/ $10.1515 / 2154-3348.1062$

Rich, A. (2004). Think tanks, public policy, and the politics of expertise. Cambridge: Cambridge University Press.

Rothstein, B. (1992). Den korporativa staten. Intresseorganisationer och statsförvaltning $i$ svensk politik. Stockholm: Norstedts.

Rothstein, B., \& Bergström, J. (1999). Korporatismens fall och den svenska modellens kris. Stockholm: SNS.

Salamon, L. M., \& Anheier, H. K. (1998). Social origins of civil society: Explaining the nonprofit sector cross-nationally. Voluntas: International Journal of Voluntary and Nonprofit Organizations, 9(3), 213-248.

Salamon, L., Sokolowski, W., \& Haddock, M. (2017). Explaining civil society development. A Social Origins Approach. Baltimore: John Hopkins University Press.

Saldana, J. (2013). The coding manual for qualitative researchers. London: Sage.

Schmitter, P. C. (1981). Interest intermediation and regime governability in contemporary Western Europe and North America. In S. Berger (Ed.), Organizing interests in Western Europe: Pluralism, corporatism and the transformation of politics. Cambridge: Cambridge University Press.

Selle, P., Strømsnes, K., Svedberg, L., Ibsen, B., \& Henriksen, L. (2018). The Scandinavian organizational landscape: Extensive and different. In L. Henriksen, K. Strømsnes, \& L. Svedberg (Eds.), Scandinavian civic engagement: Volunteering, informal help and giving in Denmark, Norway and Sweden. New York: Springer.

Siaroff, A. (1999). Corporatism in 24 industrial democracies: Meaning and measurement. European Journal of Political Research, 36(2), 175-205.
Sivesind, K.-H. (2016). Mot en ny Skandinavisk velferdsmodell? Konsekvenser av ideell, kommersiell og offentlig tjensteyting for aktivt medborgarskap (Vol. 1). Oslo: Institutt for Samfunnsforskning.

Skocpol, T. (2003). Diminished democracy: From membership to management in American civic life. Norman: University of Oklahoma Press.

Stone, D. (1996). Capturing the political imagination: Think tanks and the policy process. London: Frank Cass.

Stone, D. (2000). Think tank transnationalisation and non-profit analysis: Advice and advocacy. Global Society, 14(2), 153-172.

Stone, D., \& Denham, A. (Eds.). (2004). Think tank traditions: Policy research and the politics of ideas. Manchester: Manchester University Press.

Stone, D., \& Garnett, M. (1998). Introduction: Think tanks, policy advice and governance. In D. Stone, A. Denham, \& M. Garnett (Eds.), Think tanks across nations: A comparative approach. Manchester: Manchester University Press.

Trägårdh, L. (2010). Rethinking the Nordic welfare state through a neo-Hegelian theory of state and civil society. Journal of Political Ideologies, 15(3), 227-239.

von Essen, J. (2019). The shifting meanings of popular engagement in Swedish society. VOLUNTAS: International Journal of Voluntary and Nonprofit Organizations, 30(1), 29-40.

von Essen, J., \& Åberg, P. (2009). Folkrörelseanknytningar och marknadsrelationer. Studieförbunden och deras grundarorganisationer, medlemsorganisationer och samverkansorganisationer. Stockholm: Folkbildningsrådet.

von Essen, J., \& Sundgren, G. (Eds.). (2012). En mosaik av mening: Om studieförbund och civilsamhälle. Göteborg: Daidalos.

Weaver, R. K. (1989). The changing world of think tanks. PS: Political Science and Politics, 22(3), 563-578.

Weaver, R. K., \& Stares, P. B. (Eds.). (2001). Guidance for governance: Comparing alternative sources of public policy advice. New York: Japan Center for International Exchange.

Wijkström, F. (2011). 'Charity Speak' and 'Business Talk'. The ongoing (re-)hybridization of civil society. In F. Wijkström \& A. Zimmer (Eds.), Nordic civil society at a cross-roads: The transformation of the popular movement tradition. BadenBaden: Nomos.

Wijkström, F. (Ed.). (2012). Civilsamhället $i$ samhällskontraktet. En antologi om vad som stair pa spel. Stockholm: European Civil Society Press.

Wijkström, F. (2017). Nytt svängrum för filantropi och frivillighet. In F. Wijkström, M. Reuter, \& A. Emami (Eds.), Civilsamhället $i$ det transnationella rummet. Stockholm: European Civil Society Press.

Wijkström, F., \& Einarsson, T. (2006). Frän nationalstat till näringsliv? Det civila samhällets organisationsliv i förändring. Stockholm: EFI, Stockholm School of Economics.

Wijkström, F., \& Einarsson, S. (2018). Comparing Swedish foundations: A carefully negotiated space of existence. American Behavioral Scientist, 62(13), 1889-1918.

Williamson, P. J. (1985). Varieties of corporatism: A conceptual discussion. Cambridge: Cambridge University Press.

Publisher's Note Springer Nature remains neutral with regard to jurisdictional claims in published maps and institutional affiliations. 